\title{
Biodegradable Films Based on Gelatin and Montmorillonite Produced by Spreading
}

\author{
Manuel Fernando Coronado Jorge, Elisabete M. C. Alexandre, \\ Christian Humberto Caicedo Flaker, Ana Mônica Quinta Barbosa Bittante, \\ and Paulo José do Amaral Sobral
}

Department of Food Engineering, FZEA, University of São Paulo, Avenida Duque de Caxias Norte 225, 13635-900 Pirassununga, SP, Brazil

Correspondence should be addressed to Paulo José do Amaral Sobral; pjsobral@usp.br

Received 9 March 2015; Revised 22 May 2015; Accepted 30 May 2015

Academic Editor: Xingxun Liu

Copyright (C) 2015 Manuel Fernando Coronado Jorge et al. This is an open access article distributed under the Creative Commons Attribution License, which permits unrestricted use, distribution, and reproduction in any medium, provided the original work is properly cited.

\begin{abstract}
The main objective of this research was to study the properties of gelatin-based nanocomposites reinforced with the montmorillonite (MMT). The gelatin-based nanocomposites were prepared with solutions of $5 \mathrm{~g}$ of gelatin/100 g of film-forming solution, $0-10 \mathrm{~g}$ of montmorillonite/100 $\mathrm{g}$ of gelatin, and $30 \mathrm{~g}$ of glycerol/100 $\mathrm{g}$ of gelatin and were stored for $7 \mathrm{days}$ at $58 \%$ relative humidity or in silica gel, depending on the type of assay. The reinforcement of gelatin-based nanocomposites with montmorillonite increased their thickness and decreased the moisture content. Tensile strength and Young's modulus increased revealing more resistant and rigid nanocomposites. The increase in MMT concentration slightly changed the X-ray diffraction spectra indicating some loss of crystallinity and reinforced films presented less homogeneous structures. The montmorillonite concentration had not a clear effect on the thermal properties and FTIR spectra of nanocomposites were very similar to separated compounds.
\end{abstract}

\section{Introduction}

The accumulation of plastic packaging in nature is one of the major environmental problems representing a big challenge in terms of waste treatment and recycling. The development of biopolymers-based films that can replace synthetic materials may be a good alternative, particularly for the food packaging industry. Polysaccharides and proteins are the main biopolymers used in the preparation of such edible and/or biodegradable films $[1,2]$.

Proteins are macromolecules of interest because they have a structure based on 20 different monomers (amino acid residues), allowing a wider range of functional properties (especially a high intermolecular binding potential) [3] Gelatin has been one of the most well-studied protein based materials because of its excellent film-forming property and its usefulness as an outer film to protect food by acting as a barrier to gases, and it is produced at relatively low cost all over the world [4]. Gelatin is a protein with the ability to form a tridimensional network, with crystalline intermolecular linking zones. The gelatin gel formation involves the change from a disorganized state to a more arranged state, formed by triple-helix structures typical of collagen in its native state. This structure and physical properties of the gels are a result of the degree of formation of microcrystalline junctions [5].

Gelatin-based films usually present good mechanical resistance and high elasticity but are also sensitive to environmental conditions, as relative humidity, and are affected by several factors such as $\mathrm{pH}$, heat treatment, addition of plasticizers, ion concentration, protein concentration, and its molecular conformation [6]. An alternative to enhance the gelatin-based films properties that has attracted the interest of researchers is related to the reinforcement of films with nanoparticles, producing a material often called bionanocomposites or only nanocomposites [7-9]. The nanocomposites films are thin materials formed by a biopolymer matrix reinforced with a dispersed nanoscale filler. The mechanical and barrier properties are improved 
mainly due to the reinforcing effect of the particles, thermal stability usually increases (the thermal expansion coefficient is reduced), and the transparency is usually retained if a perfect dispersion of nanometer-sized filler particles into polymer is achieved [10-14]. The atomic and molecular interactions can also have a significant influence on the macroscopic properties, particularly when the domain size of the load is comparable to the size of the molecule [15].

One of the most widely used nanoparticles in studies of biopolymer-based nanocomposites is the montmorillonite (MMT). MMT is a layered silicate characterized by a moderate negative surface charge [16] that displays a perfect crystalline structure, formed by a two-dimensional layer having a central octahedral sheet of aluminum oxide and magnesium oxide linked with two external silica tetrahedrons [17].

The main objective of this research was to study the properties (physical properties, phase transitions, and microstructure) of gelatin-based nanocomposites reinforced with the montmorillonite (MMT) and produced by spreading.

\section{Material and Methods}

2.1. Material. The biopolymer used was a pigskin gelatin (bloom 242-248; molecular weight $\approx 5.2 \times 10^{4} \mathrm{Da}$; moisture content $=9.3 \%$ ) that was kindly provided by Gelita South America (São Paulo, Brazil). Glycerol (Synth) was the plasticizer and MMT nanoparticles (Nanomer clay, Aldrich, reference number 688659-500G) were the filler. Distilled water was used as solvent to prepare film-forming solutions.

\subsection{Production of Nanocomposite-Forming Solutions Based on} Gelatin and Montmorillonite. The nanocomposite-forming solutions (NFS) were produced from a mixture of gelatin $(5 \mathrm{~g}$ of gelatin/100 $\mathrm{g}$ of NFS), MMT nanoparticles $(0,5$, and $10 \mathrm{~g}$ of MMT/100 g of gelatin), and glycerol (30 $\mathrm{g}$ of glycerol/100 $\mathrm{g}$ of gelatin). The concentration of gelatin was fixed in $5 \mathrm{~g}$ of gelatin/100 $\mathrm{g}$ of NFS because preliminary tests revealed that nanocomposites produced with a gelatin concentration in NFS greater than $8 \%$ were not homogeneous due to the formation of agglomerates [8].

The NFS was prepared in two parallel steps. On one hand, the gelatin was hydrated in distilled water for $30 \mathrm{~min}$ at room temperature and then dissolved at $70^{\circ} \mathrm{C}$ for $30 \mathrm{~min}$ using a thermostatic bath (Marconi, model MA 179). On the other hand and at the same time, the MMT was hydrated at room temperature in distilled water containing the glycerol, for 40 min under magnetic agitation. Then, this dispersion was submitted to high speed agitation using a high speed homogenizer (Ultraturrax Ika, model T18 basic) at $18.000 \mathrm{rpm}$ for $10 \mathrm{~min}$. In order to eliminate the air bubbles formed, the dispersion was also treated in an ultrasound bath (Unique, model MaxiClean 1400) at $60^{\circ} \mathrm{C}$ for $10 \mathrm{~min}$. After that, the MMT dispersion and the gelatin solution were homogenized under mechanical agitation (Tecnal, model TE 039) conditions for $2 \mathrm{~min}$ at $70^{\circ} \mathrm{C}$. A control film without montmorillonite was also prepared. Three replicates of each film were prepared.
2.3. Nanocomposite Production. The nanocomposites were produced by spreading the NFS over acrylic plates $(26 \times 30$ $\times 0.2 \mathrm{~cm}$ ) using an automatic film spreader (TKB Erichsen, model Speed II). The spreading knife speed was set at $35 \mathrm{~mm} / \mathrm{s}$; the gap between the knife and the plate was $1.5 \mathrm{~mm}$. The acrylic plate was maintained at $25^{\circ} \mathrm{C}[8,9]$. The nanocomposites were oven-dried for $24 \mathrm{~h}$ at $30^{\circ} \mathrm{C}$ (Marconi, MA 035).

2.4. Nanocomposite Characterization. Nanocomposites produced with and without MMT were characterized in terms of thickness, humidity, mechanical properties (tensile and puncture tests), and thermal properties after 7 days conditioning over $\mathrm{NaBr}$ ( $58 \%$ of relative humidity at $25^{\circ} \mathrm{C}$ ). For scanning electron microscopy (SEM) analyses, film crystallinity, Fourier transform infrared (FTIR) spectroscopy, and superficial hydrophobicity assays, all samples were conditioned in desiccators containing silica gel.

All measurements were made in air-conditioned rooms at $22^{\circ} \mathrm{C}, 55$ to $65 \%$ relative humidity, in triplicate.

The thickness of the nanocomposites was measured with a digital micrometer $( \pm 0.001 \mathrm{~mm}$; Mitutoyo, Japan $)$ with a $6.4 \mathrm{~mm}$ diameter probe, taking the average at ten different positions of each sample [18].

The moisture content of the nanocomposites was determined gravimetrically according to the ASTM standard method D644-99, by drying the samples at $105^{\circ} \mathrm{C}$ for $24 \mathrm{~h}$ (ASTM 1999).

The mechanical properties were determined by the tensile test (tensile strength-TS, elongation at break-EB, and Young's modulus-YM) and puncture tests (puncture force$\mathrm{PF}$, and puncture deformation-PD) using the TA.XT2i texturometer (TA Instruments, Surrey, UK), according to the methodology previously described by Thomazine et al. [19] and Gontard et al. [20], respectively.

For the tensile tests, samples from each nanocomposite were cut into small rectangles $(15 \times 100 \mathrm{~mm})$ and fixed in the grips probe. The initial grip separation distance was fixed in $50 \mathrm{~mm}$ and the moving rate set was $0.9 \mathrm{~mm} / \mathrm{s}$. At least 15 samples from each film were tested. The tensile strength (force at the break/initial cross-sectional area) and elongation at break $(\Delta l / l o)$ were calculated with the Exponent Lite Express Software v.4.0.13.0 (2007) directly from the stressstrain curves and the elastic modulus was calculated as the slope of the initial linear portion of this curve.

For the puncture test, circular samples of nanocomposites were fixed in a $52.6 \mathrm{~mm}$ diameter cell and perforated by a $3 \mathrm{~mm}$ diameter probe moving at $1 \mathrm{~mm} / \mathrm{s}$, in triplicate. The puncture force $(\mathrm{PF}, \mathrm{N})$ and the displacement of the probe $(D$, $\mathrm{cm})$ at the perforation point were determined directly from the force-displacement curves, using the same software [18].

Thermal properties of nanocomposites were analyzed by DSC to determine the glass transition temperatures. These analyses were performed using a differential scanning calorimeter (DSC TA2010) controlled by a TA5000 system (TA Instruments, New Castle, DE, USA) and equipped with a cryogenic quench cooling accessory. The samples of nanocomposites $(\sim 10 \mathrm{mg})$ were placed in hermetically sealed aluminum TA pans and heated from -50 to $200^{\circ} \mathrm{C}$ at a heating rate of $5^{\circ} \mathrm{C} / \mathrm{min}$, in double run, always after cooling with 
liquid nitrogen in an inert atmosphere $\left(45 \mathrm{~mL} / \mathrm{min}\right.$ of $\left.\mathrm{N}_{2}\right)$ [21]. An empty pan was used as reference. The sample weight was measured with a high resolution $( \pm 0.00001 \mathrm{~g})$ balance (Ohaus, Analytical Plus). The results were analyzed using the Universal Analysis V1.7F (TA Instruments) software. The temperature where a baseline inflexion occurred was taken as the glass transition temperature. The peak temperature of the endothermic event observed in the thermogram was taken as the melting temperature.

Film crystallinity was evaluated qualitatively by measuring the X-ray diffraction (XRD) with an X-ray diffractometer (RU200B, Rigaku Rotaflex) using a Cu source, according to the method described by Angellier et al. [22].

Fourier transform infrared (FTIR) spectra were recorded using a Perkin Elmer spectrometer Spectrum One (Perkin Elmer, USA) equipped with a universal attenuated total reflectance (UATR) accessory, according to Vicentini et al. [23]. Twenty scans were coadded and recorded between 650 and $4000 \mathrm{~cm}^{-1}$ with a $2 \mathrm{~cm}^{-1}$ spectral resolution. The FTIR Spectrum Software (Perkin Elmer) was used to analyze the data.

Scanning electron microscopy (SEM) was used to analyze the superficial and internal microstructure of nanocomposites. The samples were maintained in a desiccator with silica gel under vacuum for 1 week and then mounted on an aluminum stub using a double-sided copper tape. Further, the nanocomposites were immersed in liquid nitrogen and fractured to analyze the internal microstructure. All analyses were performed using a SEM (Hitachi, Japan, model TM30000) operating at $15 \mathrm{kV}$ according to Lu et al. [24].

Surface hydrophobicity characteristics of the nanocomposites were evaluated by contact angle measurements using a contact angle meter (Optical Tensiometer, Finland). A drop of ultrapure water with an estimated volume of $10 \mu \mathrm{L}$ was deposited on the film sample surface $\left(3 \times 4 \mathrm{~cm}^{2}\right)$ with a precision syringe (Hamilton Gastight Syringes, USA) and immediately photographed. The Attension Theta Optical Tensiometer lite Software was used to measure the angle between the drop base (film surface in contact with the water drop) and the tangent to the drop of water. Contact angle measurements were obtained for both sides of the film.

2.5. Statistical Analyses. Experimental data were analyzed to determine whether the variances are statistically homogeneous. The results are expressed as means \pm SD. Statistical comparisons were made by analysis of variance followed by Tukey's multiple range tests using the "Statistical Analysis Systems" software (version 9.2, SAS, Statistical Analysis Systems, NC, USA). A significance level was set at 0.05 .

\section{Results and Discussion}

3.1. Thickness and Moisture Content. The average thickness and moisture content of nanocomposites obtained with $5 \mathrm{~g}$ of gelatin/100 $\mathrm{g}$ of NFS and different concentrations of MMT after 7 days of storage under $58 \%$ of relative humidity are shown in Table 1. The incorporation of MMT in gelatinbased films increased their thickness. Samples without MMT
TABLE 1: Average thickness, moisture content, and contact angle of the films ( \pm standard deviation) prepared with $5 \mathrm{~g}$ of gelatin $/ 100 \mathrm{~g}$ NFS and different MMT concentrations.

\begin{tabular}{lccc}
\hline $\begin{array}{l}\text { MMT (g of } \\
\text { montmorillonite/ } \\
100 \text { g of gelatin) }\end{array}$ & $\begin{array}{c}\text { Thickness } \\
(\mathrm{mm})\end{array}$ & $\begin{array}{c}\text { Moisture } \\
\text { content }(\%)\end{array}$ & $\begin{array}{c}\text { Angle with } \\
\text { upper surface }\left(^{\circ}\right)\end{array}$ \\
\hline 0 & $0.071 \pm 0.007^{\mathrm{a}}$ & $20.4 \pm 1.4^{\mathrm{a}}$ & $90.3 \pm 10.7^{\mathrm{a}}$ \\
5 & $0.077 \pm 0.005^{\mathrm{b}}$ & $18.3 \pm 1.1^{\mathrm{b}}$ & $94.6 \pm 2.2^{\mathrm{a}}$ \\
10 & $0.080 \pm 0.010^{\mathrm{b}}$ & $17.3 \pm 0.9^{\mathrm{b}}$ & $82.9 \pm 8.0^{\mathrm{a}}$ \\
\hline
\end{tabular}

Values with different characters differ significantly in the same column $(p<$ 0.05).

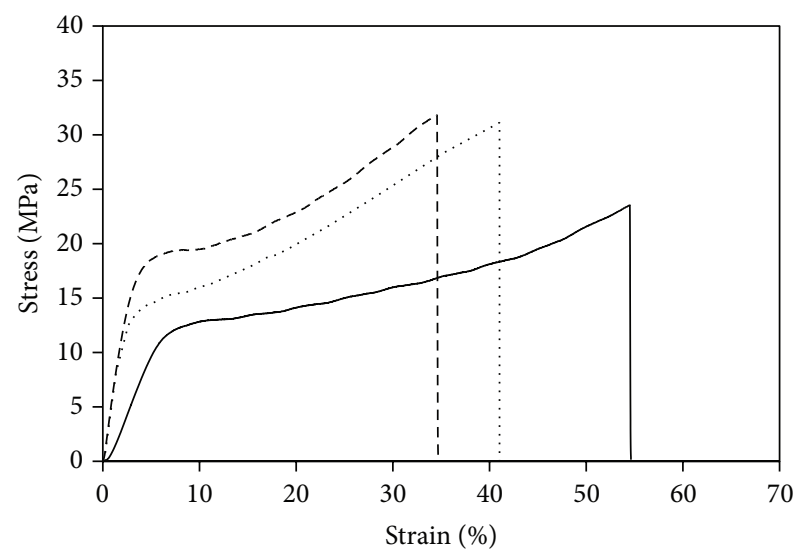

FIGURE 1: Typical curves for the tensile properties of the nanocomposites prepared with $5 \mathrm{~g}$ of gelatin/100 $\mathrm{g}$ of NFS and $0(-), 5(\cdots)$, and 10 (- - ) $\mathrm{g}$ of MMT/100 $\mathrm{g}$ of gelatin.

presented $0.071 \pm 0.007 \mathrm{~mm}$ which was significantly different from $0.077 \pm 0.005$ and $0.080 \pm 0.010 \mathrm{~mm}$ obtained for nanocomposites prepared with 5 and $10 \mathrm{~g}$ of MMT/100 $\mathrm{g}$ of gelatin, respectively. Jang et al. [25] used a casting technique and observed no significant effect of nanoparticles on the thickness of the films (based on gelatin and agar). However, Sothornvit et al. [26] observed that the films thickness increased with the addition of nanoparticles in whey protein isolate based composite films.

The charges of MMT decreased significantly the moisture content of the samples. Nanocomposites without MMT presented $20.4 \pm 1.4 \%$ of moisture while nanocomposites prepared with 5 and $10 \mathrm{~g}$ of MMT/100 $\mathrm{g}$ of gelatin had $18.3 \pm$ 1.1 and $17.3 \pm 0.9 \%$ of moisture, respectively. This suggests that MMT decreased the sensitivity of the nanocomposites to the environment humidity. Tunç et al. [16] observed a similar behavior when studying the functional properties of wheat gluten/MMT $(1,2.5,5,7.5$, and $10 \mathrm{wt} \%)$ nanocomposite processed by casting and attributed this behavior to a different structuring of protein network in the presence of MMT.

3.2. Mechanical Properties. Typical curves obtained through the tensile tests are shown in Figure 1. In general, the increase in MMT concentration slightly changed the shape of stress versus strain curves. The tensile strength and Young's modulus increased with the MMT concentration, from $23.5 \pm 3.1$ to 
TABLE 2: Tensile strength (TS), Young's modulus (YM), elongation at break (EB), puncture force (PF), and puncture deformation (PD) for films prepared with $5 \mathrm{~g}$ of gelatin/100 $\mathrm{g}$ of NFS and different MMT concentrations and stored under $58 \%$ of RH.

\begin{tabular}{|c|c|c|c|c|c|}
\hline $\begin{array}{l}\text { MMT } \\
\text { ( } \mathrm{g} \text { of montmorillonite/100 } \mathrm{g} \text { of gelatin) }\end{array}$ & TS (MPa) & $\mathrm{YM}(\mathrm{MPa} / \%)$ & $\mathrm{EB}(\%)$ & $\mathrm{PF}(\mathrm{N})$ & PD (\%) \\
\hline 0 & $23.5 \pm 3.1^{\mathrm{a}}$ & $2.1 \pm 0.6^{\mathrm{a}}$ & $48.7 \pm 5.5^{\mathrm{a}}$ & $15.5 \pm 1.1^{\mathrm{a}}$ & $5.3 \pm 0.5^{\mathrm{a}}$ \\
\hline 5 & $31.7 \pm 1.8^{\mathrm{b}}$ & $5.5 \pm 1.0^{\mathrm{b}}$ & $40.4 \pm 3.4^{\mathrm{b}}$ & $15.7 \pm 0.8^{\mathrm{a}}$ & $7.3 \pm 0.6^{\mathrm{b}}$ \\
\hline 10 & $31.1 \pm 1.9^{\mathrm{b}}$ & $6.6 \pm 0.2^{c}$ & $38.0 \pm 3.4^{\mathrm{b}}$ & $15.6 \pm 0.8^{\mathrm{a}}$ & $5.8 \pm 1.1^{\mathrm{a}}$ \\
\hline
\end{tabular}

Values with different characters differ significantly in the same column $(p<0.05)$.

TABLE 3: Glass transition temperatures, enthalpy, and fusion temperature for nanocomposites prepared with $5 \mathrm{~g}$ of gelatin/100 $\mathrm{g}$ of NFS and different MMT concentrations and stored under $58 \%$ of $\mathrm{RH}$.

\begin{tabular}{lcccc}
\hline \multirow{2}{*}{ MMT (g of montmorillonite/100 g of gelatin) } & \multicolumn{2}{c}{ Glass transition temperature } & Enthalpy $(\mathrm{J} / \mathrm{g})$ & Fusion temperature $\left({ }^{\circ} \mathrm{C}\right)$ \\
\hline First scan & $T_{g_{1}}\left({ }^{\circ} \mathrm{C}\right)$ & $T_{g_{2}}\left({ }^{\circ} \mathrm{C}\right)$ & & \\
$\quad$ & & & \\
0 & $-74.3 \pm 1.2^{\mathrm{a}}$ & $43.1 \pm 1.0^{\mathrm{a}}$ & $20.0 \pm 0.6^{\mathrm{a}}$ & $66.8 \pm 0.6^{\mathrm{a}}$ \\
5 & $-73.8 \pm 2.2^{\mathrm{a}}$ & $45.7 \pm 0.5^{\mathrm{ab}}$ & $20.6 \pm 0.5^{\mathrm{a}}$ & $69.1 \pm 0.4^{\mathrm{a}}$ \\
10 & $-75.3 \pm 1.1^{\mathrm{a}}$ & $45.8 \pm 1.3^{\mathrm{b}}$ & $17.7 \pm 1.3^{\mathrm{b}}$ & $68.9 \pm 1.0^{\mathrm{a}}$ \\
Second scan & & & & \\
0 & $-74.2 \pm 3.8^{\mathrm{a}}$ & $31.5 \pm 1.5^{\mathrm{a}}$ & & \\
5 & $-75.7 \pm 2.2^{\mathrm{a}}$ & $33.6 \pm 1.3^{\mathrm{a}}$ & & \\
10 & $-74.3 \pm 4.0^{\mathrm{a}}$ & $32.0 \pm 2.3^{\mathrm{a}}$ & & \\
\hline
\end{tabular}

Values with different characters differ significantly in the same column $(p<0.05)$.

$31.7 \pm 1.8 \mathrm{MPa}$ (for $5 \%$ of MMT) and $31.1 \pm 1.9 \mathrm{MPa}$ (for $10 \%$ of MMT) and from $2.1 \pm 0.6$ to $5.5 \pm 1.0 \mathrm{MPa} / \%$ (for $5 \%$ of $\mathrm{MMT}$ ) and $6.6 \pm 0.2 \mathrm{MPa} / \%$ (for $10 \%$ of MMT), respectively (Table 2).

The elongation at break decreased with the introduction of MMT from $48.7 \pm 5.5$ to $40.4 \pm 3.4$ and $38.0 \pm 3.4 \%$ for 5 and $10 \%$ of MMT, respectively, indicating that the polymeric matrix was reinforced by the addition of nanoparticles. Cyras et al. [27] and Rao [15] also observed an improvement in mechanical properties of nanocomposites based on starch and gelatin, respectively. Rao [15] verified that a load of 5\% of MMT increased by $75 \%$ the Young modulus and by $25 \%$ the tensile strength. The increase in tensile strength and Young's modulus for nanocomposites reinforced with $10 \%$ of MMT was $24 \%$ and $68 \%$, respectively.

Bae et al. [28] observed that increasing the amount of MMT increased the tensile strength of the nanocomposites based on fish gelatin. However, Rao [15] and Cyras et al. [27] analyzed the effects of MMT concentration from 0 to $9 \%$ and verified that the highest values of tensile strength were achieved for a concentration of $5 \%$ of MMT. Similarly, Luecha et al. [29], working with concentrations of $0-10 \%$ of MMT in corn zein/montmorillonite nanocomposite, observed that maximum tensile strength for samples with 5\% of MMT doubled with respect to films with $0 \% \mathrm{MMT}$ as well as Tunç and Duman [30] studying a matrix of gluten. Jang et al. [25], working with nanocomposites of gelatin and agar, obtained the maximum tensile strength with 3\% MMT. These results show that the technique so-called "casting," and by similarity the spreading technique, required a critical percentage of MMT to obtain intercalated or exfoliated structures.

In relation to results of puncture tests, the puncture force of nanocomposites prepared without MMT $(15.5 \pm 1.1 \mathrm{~N})$ or reinforced with MMT $(15.7 \pm 0.8 \mathrm{~N}$ for $5 \% \mathrm{MMT}$ and $15.6 \pm$ $0.8 \mathrm{~N}$ for $10 \% \mathrm{MMT}$ ) was not statistically different (Table 2 ). Puncture deformation of nanocomposites reinforced with $10 \mathrm{~g}$ of MMT/100 $\mathrm{g}$ of gelatin $(5.8 \pm 1.1 \%)$ was also statistically similar to control $(5.3 \pm 0.5 \%)$, while $5 \mathrm{~g}$ of MMT/100 $\mathrm{g}$ of gelatin led to nanocomposites with a higher puncture deformation $(7.3 \pm 0.6 \%)$. Moreover, when the results of mechanical properties were analyzed as a function of thickness, a clear effect of film thickness on the mechanical properties obtained by puncture tests was not observed. Sobral [31] observed that the puncture force in Tilapia myofibrillar protein films increased linearly as a function of the thickness, however without effect on puncture deformation.

3.3. Thermal Properties. In general, the DSC thermograms of all nanocomposites were very similar (Figure 2 ). In the first scan, the curves were typical of partially crystalline material, while in the second scan, the curves were typical of amorphous material. A phase separation between the fraction rich in glycerol and the fraction rich in gelatin was also observed. Sobral and Habitante [21] obtained similar thermograms using gelatin films, as well as Rao [15], but using gelatin-based nanocomposites.

The MMT concentration had not a clear effect on the thermal properties (Table 3). The melting enthalpy of nanocomposites reinforced with the highest MMT concentration $(17.7 \pm 1.3 \mathrm{~J} / \mathrm{g})$ was significantly lower than that obtained with pure gelatin films $(20.0 \pm 0.6 \mathrm{~J} / \mathrm{g})$ and the glass transition temperature of gelatin-rich fraction determined during first scan increased from $43.1 \pm 1.0^{\circ} \mathrm{C}$ in gelatin films to $45.8 \pm 1.3^{\circ} \mathrm{C}$ for nanocomposites with $10 \mathrm{~g}$ MMT/100 g gelatin. On the other hand, the glass transition temperature of the gelatin-rich fraction, determined in the second scan, was not 

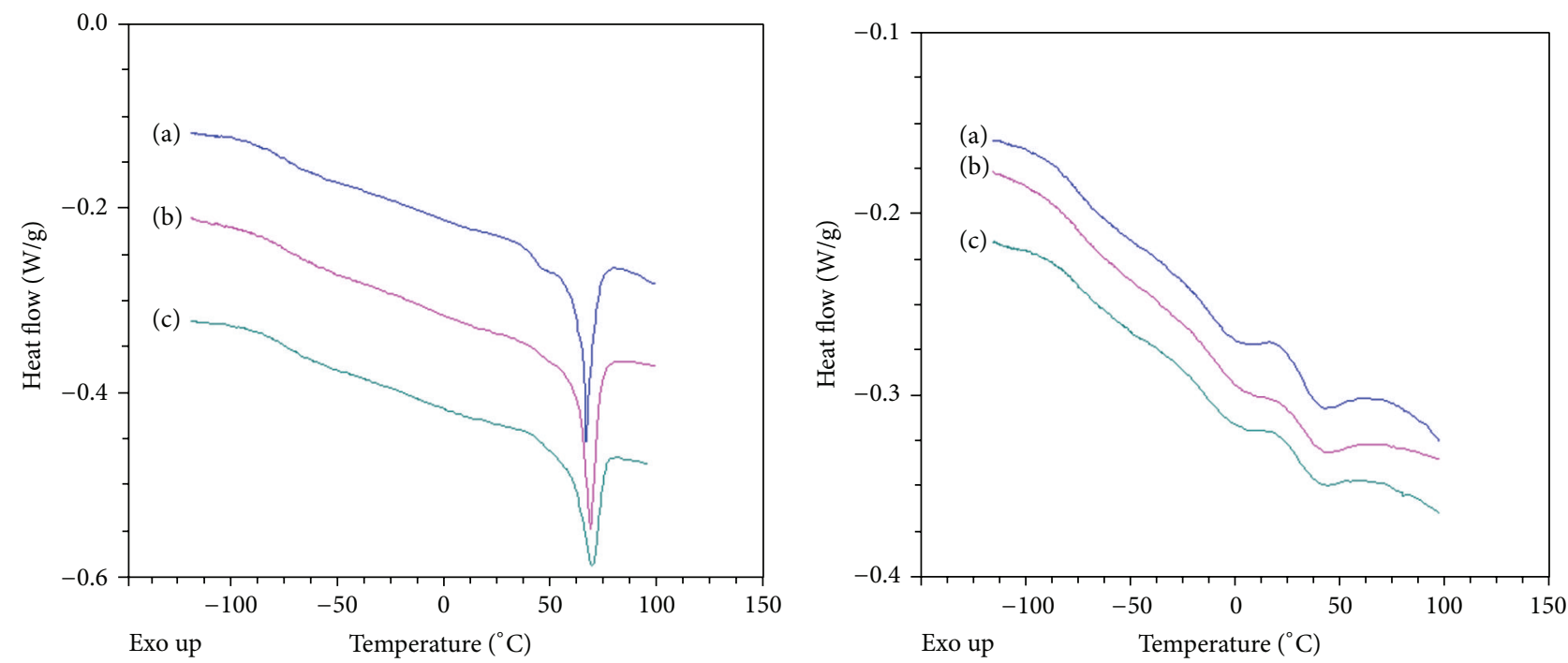

Figure 2: DSC thermograms of the first (left) and second (right) scans for $5 \%$ of gelatin nanocomposites with $0 \%$ (a), 5\% (b), and $10 \%$ (c) of MMT and stored at $58 \%$ of $\mathrm{RH}$.

significantly different for nanocomposites prepared with or without MMT.

A glass transition temperature of $31.5 \pm 1.5^{\circ} \mathrm{C}$ was obtained for films without MMT and $33.6 \pm 1.3$ and $32.0 \pm$ $2.3^{\circ} \mathrm{C}$ for nanocomposites containing 5 and $10 \mathrm{~g} \mathrm{MMT} / 100 \mathrm{~g}$ gelatin, respectively, while the glass transition temperature of glycerol-rich fraction was affected neither by MMT nor by scanning. Rao [15] also observed that the glass transition temperatures of the nanocomposites with gelatin and MMT were similar to the ones obtained for gelatin-based nanocomposites. Luecha et al. [29] obtained glass transition temperatures of the nanocomposites with zein montmorillonite around $36^{\circ} \mathrm{C}$. Rao [15] observed that the melting temperature increased slightly with the addition of montmorillonite in gelatin-based nanocomposites.

3.4. X-Ray Diffraction. The MMT powder presented an X-ray diffraction spectrum with several types of crystals; however the most relevant ones were observed for $2 \theta=7^{\circ}$ and $20^{\circ}$ (Figure 3(a)). Similar results were obtained by Faria et al. [32] and Cyras et al. [27] who also analyzed MMT samples and verified that the first peak occurred for $2 \theta$ between $7^{\circ}$ and $8^{\circ}$. The gelatin spectrum was typical of that protein presenting a predominant peak at $2 \theta=20^{\circ}$ (Figure 3(b)).

Typical X-ray diffraction spectra of 5\% gelatin-based nanocomposites with 0,5 , and $10 \%$ of MMT are shown in Figures 3(c), 3(d), and 3(e), respectively. In general, the diffraction spectra profile of the nanocomposites prepared with MMT was similar to that obtained with pure gelatin or gelatin-based nanocomposites. The increase in MMT concentration slightly changed the diffraction spectra for $2 \theta=7^{\circ}$, indicating a reduction of samples crystallinity (Figure 3(d)). Gelatin nanocomposites usually exhibit a diffraction peak in $2 \theta=7^{\circ}$, attributed to crystalline triple-helix structures of gelatin $[33,34]$, and a broad band at $2 \theta=20^{\circ}$, characteristic of an amorphous phase [34].
3.5. Fourier Transform Infrared Spectroscopy. The FTIR spectrum of gelatin and MMT powders (Figures 4(a) and 4(b)) showed quite distinct bands, predominantly in the region of amide III $\left(3283 \mathrm{~cm}^{-1}\right)$, amide II $\left(1523 \mathrm{~cm}^{-1}\right)$, and amide I $\left(1629 \mathrm{~cm}^{-1}\right)$ for gelatin and in the region of carbon and hydroxyl interaction $\left(800-1100 \mathrm{~cm}^{-1}\right)$ for MMT that should be associated with stretch of Si-O [35].

The FTIR spectra of all nanocomposites (control and both concentrations of MMT) were similar (Figures 4(c), 4(d), and $4(\mathrm{e})$ ), although a slight displacement of the bands was observed in relation to the nanocomposites formed without MMT. The concentration of MMT had no impact on the signals of band amide III $\left(3286-3289 \mathrm{~cm}^{-1}\right)$, amide II (1538$\left.1548 \mathrm{~cm}^{-1}\right)$, or amide I $\left(1630-1633 \mathrm{~cm}^{-1}\right)$.

Comparing FTIR spectra of nanocomposites with the FTIR spectrum of MMT powder, it was observed that the peak that appeared quite pronounced at $979 \mathrm{~cm}^{-1}$ in the MMT spectrum did not appear in the nanocomposite. However, a peak between 1034 and $1035 \mathrm{~cm}^{-1}$ in the spectra of nanocomposites prepared without MMT was observed, which decreased to $1029-1030 \mathrm{~cm}^{-1}$ for the nanocomposites with $10 \mathrm{~g}$ of montmorillonite $/ 100 \mathrm{~g}$ of gelatin. The peaks observed at $921 \mathrm{~cm}^{-1}$ may be due to the stretch of $\mathrm{COH}$ (plasticizer) or $\mathrm{Si}-\mathrm{O}$ (the nanoparticle). Similar spectra were observed by Silva et al. [36].

3.6. Scanning Electronic Microscopy. The gelatin nanocomposites without MMT showed a homogeneous, dense, and cohesive internal structure (Figure 5). The incorporation of MMT led to nanocomposites with internal structures less smooth, probably due to the formation of gelatin agglomerates [8]. This effect was more evident for the highest concentrations of MMT.

The incorporation of MMT also had impact on the structure of the film surfaces, the one in contact with the drying air and that in contact with the supporting acrylic 


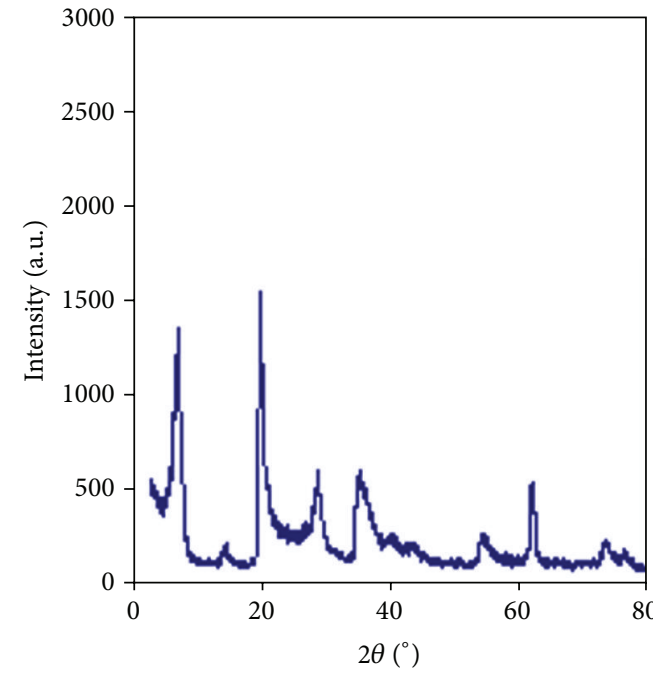

(a)

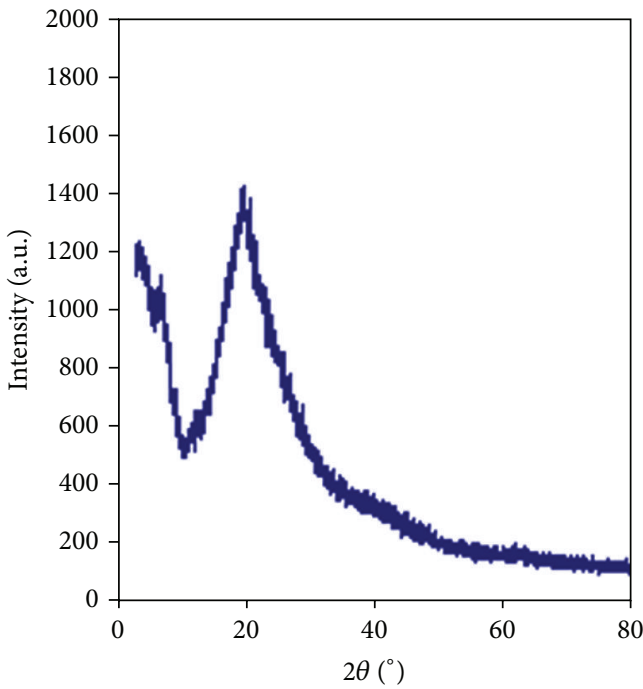

(c)

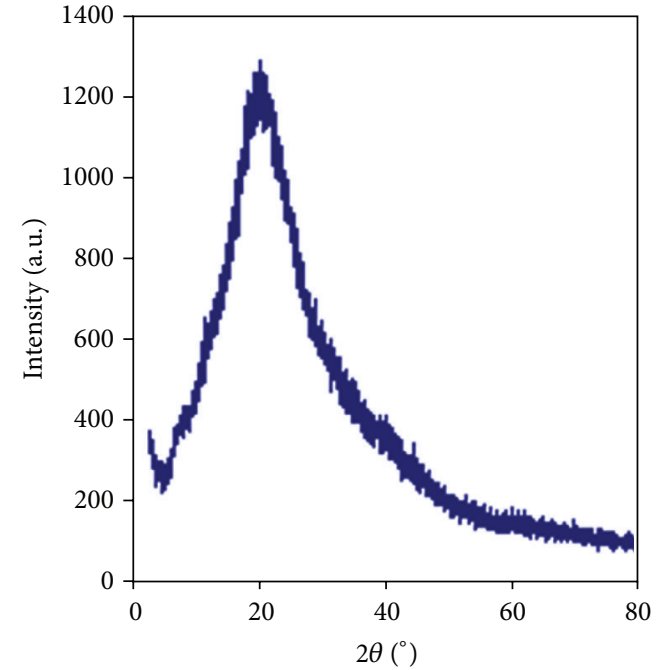

(b)

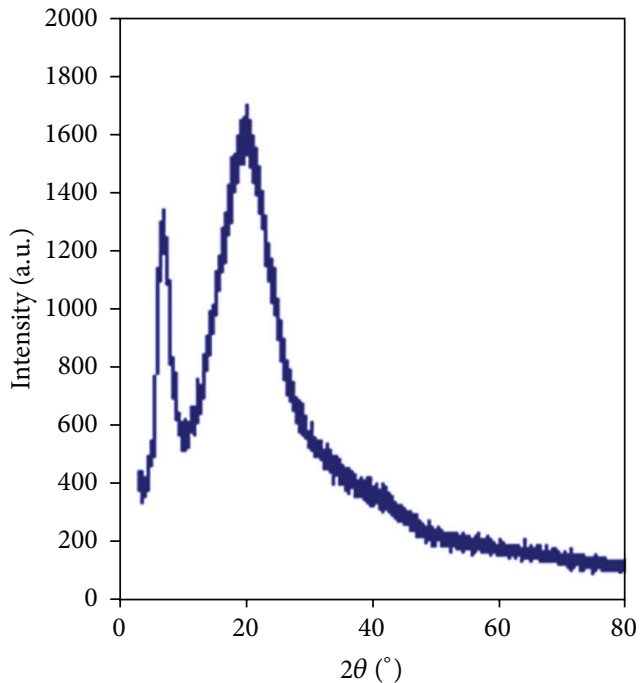

(d)

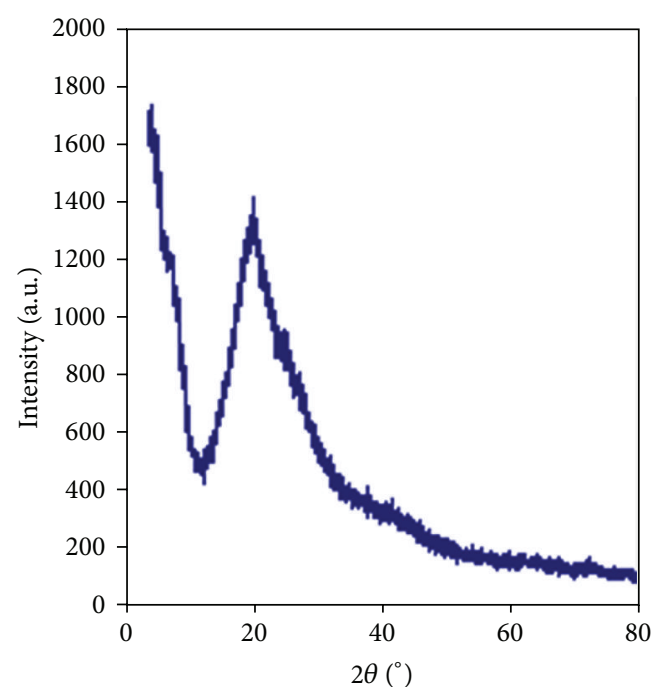

(e)

FIGURE 3: X-ray diffractograms of MMT (a), of gelatin (b), and of 5\% gelatin-based nanocomposites with (c) $0 \%$, (d) $5 \%$, and (e) $10 \%$ of MMT. 


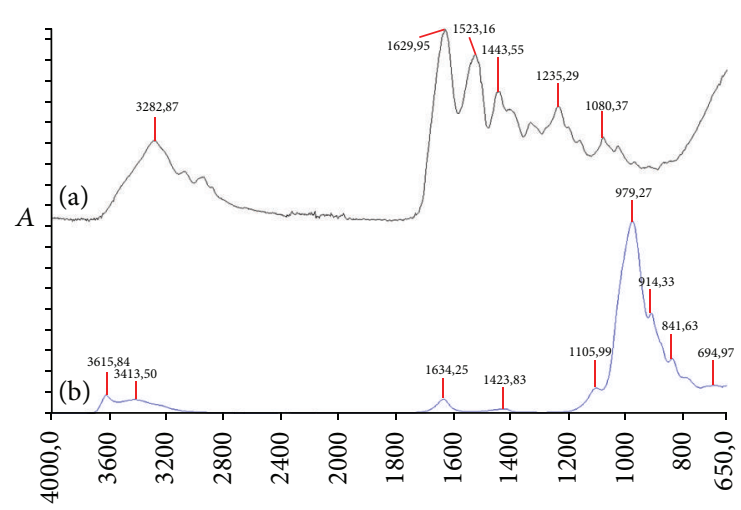

$\left(\mathrm{cm}^{-1}\right)$

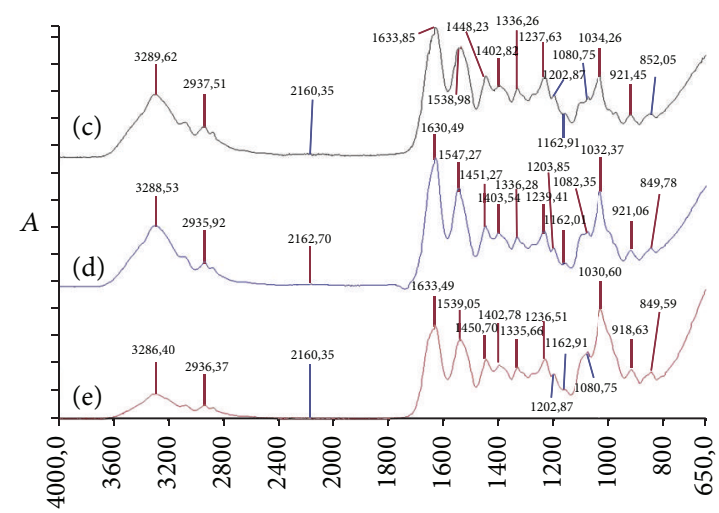

$\left(\mathrm{cm}^{-1}\right)$

FIGURE 4: FTIR spectra of (a) gelatin and (b) MMT powder and 5\% of gelatin-based nanocomposites prepared with (c) $0 \%$, (d) 5\%, and (e) $10 \%$ of MMT.

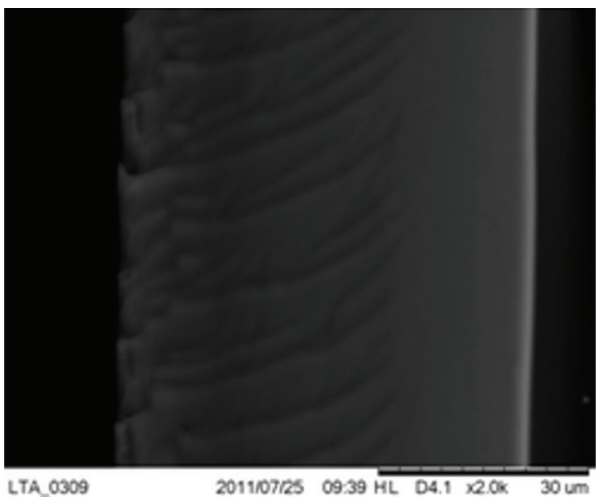

(a)

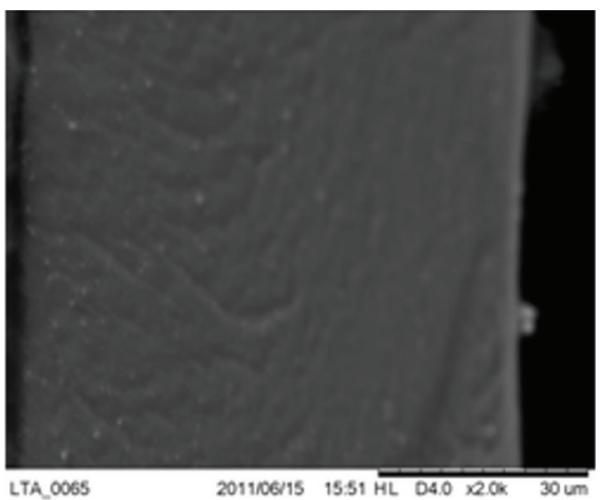

(c)

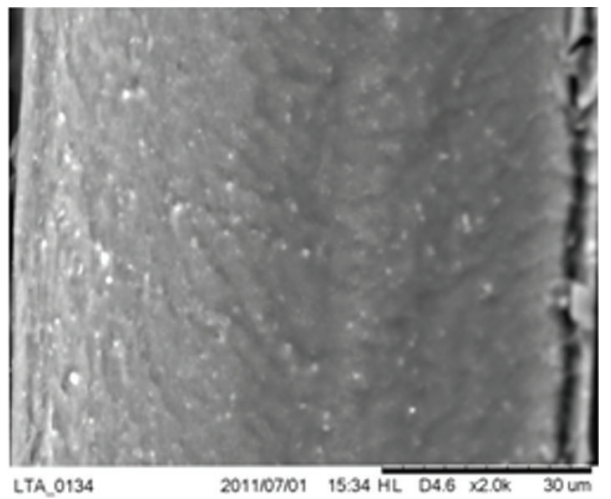

(e)

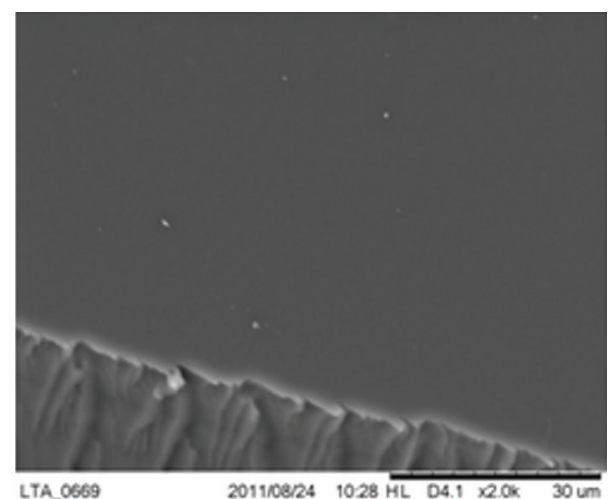

(b)

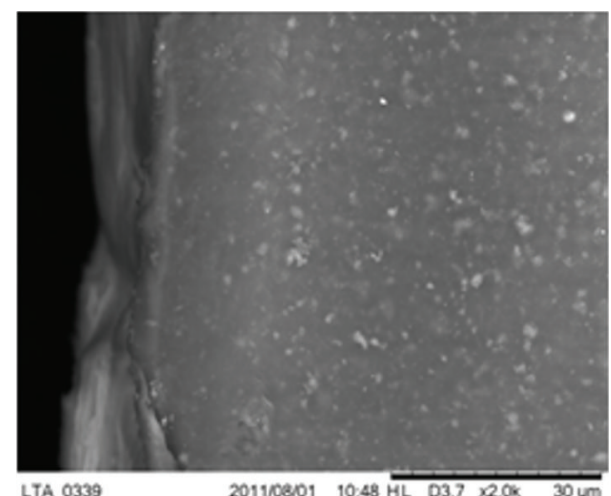

(d)

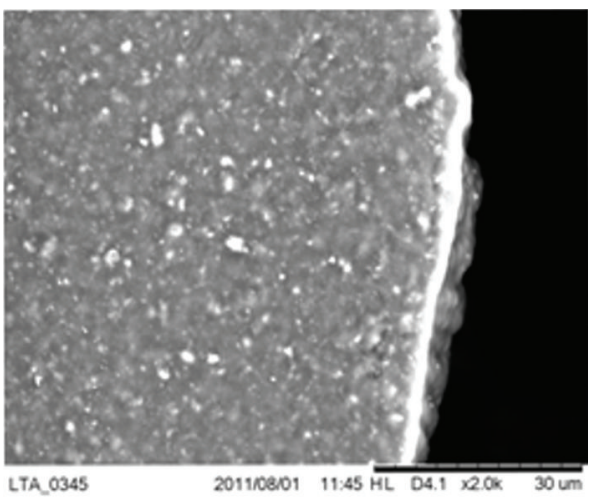

(f)

FIGURE 5: Scanning electron microscopy images of cryofractured longitudinal (left) and of the air-dried surface (right) of nanocomposites prepared with $5 \%$ of gelatin and $0 \%$ (top), $5 \%$ (center), and 10\% (bottom) of MMT. 
plate. The increase of MMT concentration led to an increase of surface roughness, losing the typical smooth surface of films prepared without MMT. A similar behavior was also observed by Rhim [37]. This behavior may be due to the formation of agglomerates, which causes less homogeneous structures or through a possible elutriation of material to the surface during the drying process.

3.7. Surface Hydrophobicity. The water contact angle measurements were carried out to study water absorption properties of the gelatin-based nanocomposites. The contact angle is dependent on the cohesive and adhesive molecular forces within the water and between the water and the film (solid) surface, respectively. Contact angles below $65^{\circ}$ are typical of hydrophilic surfaces, while contact angles above $65^{\circ}$ are characteristic of hydrophobic surfaces [38]. According to Mohan et al. [39], the hydrophilic behavior of a material can be affected by the roughness of its surface. The incorporation of nanoparticles in the formulations of gelatin-based nanocomposites had not a significant impact on nanocomposites hydrophobicity (Table 1). However, according to Rhim et al. [40], chitosan based films reinforced with MMT presented lower hydrophobicity than films prepared without MMT.

\section{Conclusions}

In general, the properties of gelatin-based nanocomposites reinforced with MMT were improved. The incorporation of MMT on gelatin-based nanocomposites led to a significant increase of their thickness and a decrease in their moisture content. The mechanical properties were improved by MMT incorporation. Reinforced nanocomposites presented higher tensile strength as well as higher Young's modulus which reveal that nanocomposites become more resistant and rigid. Consequently, the elongation at break decreased. Puncture force and puncture deformation were not affected by MMT concentration. MMT concentration had not a clear effect on the thermal properties. Only the enthalpy and glass transition of gelatin-rich fraction determined in the first scan decrease or increase, respectively, for the highest MMT concentration, but in general the glass transition temperatures were similar for all nanocomposites. The increase in MMT concentration slightly changed the X-ray diffraction spectra indicating some loss of crystallinity. FTIR spectra of the nanocomposites were similar, presenting bands typical of both gelatin and MMT. Hydrophobicity was not affected by the incorporation of MMT, but SEM results showed that reinforced nanocomposites presented structures less homogeneous.

\section{Conflict of Interests}

The authors declare that there is no conflict of interests regarding the publication of this paper.

\section{Acknowledgments}

The authors are grateful to CAPES for the Ph.D. fellowship of Manuel Fernando Coronado Jorge (PEC-PG) and to FAPESP for the MS fellowship of Christian Humberto Caicedo Flaker (11/15784-1) and Post-Doc fellowship of Elisabete M. C. Alexandre (13/25907-9). Work of the CEPID-FoRC is gratefully acknowledged (13/07914-8).

\section{References}

[1] M. O. Nisperos-Carriedo, "Edible coatings and films based on polysaccharides," in Edible Coatings and Films to Improve Food Quality, J. M. Krochta, E. A. Baldwin, and M. NisperosCarriedo, Eds., pp. 305-336, CRC Press, Boca Raton, Fla, USA, 1994.

[2] A. Nussinovitch, "Biopolymer films and composite coatings," in Modern Biopolymer Science, S. Kasapis, I. T. Norton, and J. B. Ubbink, Eds., pp. 295-326, Elsevier, San Diego, Calif, USA, 2009.

[3] M. G. A. Vieira, M. A. da Silva, L. O. dos Santos, and M. M. Beppu, "Natural-based plasticizers and biopolymer films: a review," European Polymer Journal, vol. 47, no. 3, pp. 254-263, 2011.

[4] R. Núñez-Flores, B. Giménez, F. Fernández-Martín, M. E. López-Caballero, M. P. Montero, and M. C. Gómez-Guillén, "Physical and functional characterization of active fish gelatin films incorporated with lignin," Food Hydrocolloids, vol. 30, no. 1, pp. 163-172, 2013.

[5] D. C. Achet and X. W. He, "Determination of the renaturation level in gelatin films," Polymer, vol. 36, no. 4, pp. 787-791, 1995.

[6] I. S. Arvanitoyannis, "Formation and properties of collagen and gelatin films and coatings," in Protein-Based Films and Coatings, A. Gennadios, Ed., chapter 11, pp. 275-304, CRC Press, Boca Raton, Fla, USA, 2002.

[7] C. Mu, X. Li, Y. Zhao, H. Zhang, L. Wang, and D. Li, "Freezing/thawing effects on the exfoliation of montmorillonite in gelatin-based bionanocomposite," Journal of Applied Polymer Science, vol. 128, no. 5, pp. 3141-3148, 2013.

[8] M. F. C. Jorge, C. H. C. Flaker, S. F. Nassar, I. C. F. Moraes, A. M. Q. B. Bittante, and P. J. D. A. Sobral, "Viscoelastic and rheological properties of nanocomposite-forming solutions based on gelatin and montmorillonite," Journal of Food Engineering, vol. 120, pp. 81-87, 2014.

[9] F. M. Vanin, M. H. Hirano, R. A. Carvalho, I. C. F. Moraes, A. M. Q. B. Bittante, and P. J. D. A. Sobral, "Development of active gelatin-based nanocomposite films produced in an automatic spreader," Food Research International, vol. 63, pp. 16-24, 2014.

[10] J. M. Lagarón, L. Cabedo, D. Cava, J. L. Feijoo, R. Gavara, and E. Gimenez, "Improving packaged food quality and safety. Part 2: nanocomposites," Food Additives \& Contaminants, vol. 22, no. 10, pp. 994-998, 2005.

[11] M. S. Hedenqvist, A. Backman, M. Gällstedt, R. H. Boyd, and U. W. Gedde, "Morphology and diffusion properties of whey/montmorillonite nanocomposites," Composites Science and Technology, vol. 66, no. 13, pp. 2350-2359, 2006.

[12] J. Weiss, P. Takhistov, and D. J. McClements, "Functional materials in food nanotechnology," Journal of Food Science, vol. 71, no. 9, pp. R107-R116, 2006.

[13] J.-W. Rhim, "Physical-mechanical properties of agar/ $\kappa$ carrageenan blend film and derived clay nanocomposite film," Journal of Food Science, vol. 77, no. 12, pp. N66-N73, 2012.

[14] M. Alboofetileh, M. Rezaei, H. Hosseini, and M. Abdollahi, "Effect of montmorillonite clay and biopolymer concentration 
on the physical and mechanical properties of alginate nanocomposite films," Journal of Food Engineering, vol. 117, no. 1, pp. 2633, 2013.

[15] Y. Rao, "Gelatin-clay nanocomposites of improved properties," Polymer, vol. 48, no. 18, pp. 5369-5375, 2007.

[16] S. Tunç, H. Angellier, Y. Cahyana, P. Chalier, N. Gontard, and E. Gastaldi, "Functional properties of wheat gluten/montmorillonite nanocomposite films processed by casting," Journal of Membrane Science, vol. 289, no. 1-2, pp. 159-168, 2007.

[17] M. Alexandre and P. Dubois, "Polymer-layered silicate nanocomposites: preparation, properties and uses of a new class of materials," Materials Science and Engineering R: Reports, vol. 28, no. 1, pp. 1-63, 2000.

[18] P. J. A. Sobral, F. C. Menegalli, M. D. Hubinger, and M. A. Roques, "Mechanical, water vapor barrier and thermal properties of gelatin based edible films," Food Hydrocolloids, vol. 15, no. 4-6, pp. 423-432, 2001.

[19] M. Thomazine, R. A. Carvalho, and P. J. A. Sobral, "Physical properties of gelatin films plasticized by blends of glycerol and sorbitol," Journal of Food Science, vol. 70, no. 3, pp. E172-E176, 2005.

[20] N. Gontard, S. Guilbert, and J.-L. Cuq, "Edible wheat gluten films: influence of the main process variables on film properties using response surface methodology," Journal of Food Science, vol. 57, no. 1, pp. 190-195, 1992.

[21] P. J. A. Sobral and A. M. Q. B. Habitante, "Phase transitions of pigskin gelatin," Food Hydrocolloids, vol. 15, no. 4-6, pp. 377382, 2001.

[22] H. Angellier, S. Molina-Boisseau, P. Dole, and A. Dufresne, "Thermoplastic starch-Waxy maize starch nanocrystals nanocomposites," Biomacromolecules, vol. 7, no. 2, pp. 531-539, 2006.

[23] N. M. Vicentini, N. Dupuy, M. Leitzelman, M. P. Cereda, and P. J. A. Sobral, "Prediction of cassava starch edible film properties by chemometric analysis of infrared spectra," Spectroscopy Letters, vol. 38, no. 6, pp. 749-767, 2005.

[24] Y. Lu, L. Weng, and X. Cao, "Morphological, thermal and mechanical properties of ramie crystallites-reinforced plasticized starch biocomposites," Carbohydrate Polymers, vol. 63, no. 2, pp. 198-204, 2006.

[25] S.-A. Jang, G.-O. Lim, and K. B. Song, "Original article: use of nano-clay (Cloisite $\mathrm{Na}^{+}$) improves tensile strength and vapour permeability in agar rich red algae (Gelidium corneum)-gelatin composite films," International Journal of Food Science and Technology, vol. 45, no. 9, pp. 1883-1888, 2010.

[26] R. Sothornvit, J.-W. Rhim, and S.-I. Hong, "Effect of nanoclay type on the physical and antimicrobial properties of whey protein isolate/clay composite films," Journal of Food Engineering, vol. 91, no. 3, pp. 468-473, 2009.

[27] V. P. Cyras, L. B. Manfredi, M.-T. Ton-That, and A. Vázquez, "Physical and mechanical properties of thermoplastic starch/montmorillonite nanocomposite films," Carbohydrate Polymers, vol. 73, no. 1, pp. 55-63, 2008.

[28] H. J. Bae, H. J. Park, S. I. Hong et al., "Effect of clay content, homogenization $\mathrm{RPM}, \mathrm{pH}$, and ultrasonication on mechanical and barrier properties of fish gelatin/montmorillonite nanocomposite films," LWT_Food Science and Technology, vol. 42, no. 6, pp. 1179-1186, 2009.

[29] J. Luecha, N. Sozer, and J. L. Kokini, "Synthesis and properties of corn zein/montmorillonite nanocomposite films," Journal of Materials Science, vol. 45, no. 13, pp. 3529-3537, 2010.
[30] S. Tunç and O. Duman, "Preparation and characterization of biodegradable methyl cellulose/montmorillonite nanocomposite films," Applied Clay Science, vol. 48, no. 3, pp. 414-424, 2010.

[31] P. J. A. Sobral, "Influencia da espessura sobre certas propriedades de biofilmes a base de proteinas miofibrilares," Pesquisa Agropecuária Brasileira, vol. 35, no. 6, pp. 1251-1259, 2000.

[32] F. C. Faria, A. E. S. Vercelheze, and S. Mali, "Propriedades físicas de filmes biodegradáveis a base de amido de mandioca, álcool polivinílico e montmorilonita," Química Nova, vol. 35, no. 3, pp. 487-492, 2012.

[33] I. Yakimets, S. S. Paes, N. Wellner, A. C. Smith, R. H. Wilson, and J. R. Mitchell, "Effect of water content on the structural reorganization and elastic properties of biopolymer films: a comparative study," Biomacromolecules, vol. 8, no. 5, pp. 1710$1722,2007$.

[34] M. Pereda, A. G. Ponce, N. E. Marcovich, R. A. Ruseckaite, and J. F. Martucci, "Chitosan-gelatin composites and bi-layer films with potential antimicrobial activity," Food Hydrocolloids, vol. 25, no. 5, pp. 1372-1381, 2011.

[35] S. W. Xu, J. P. Zheng, L. Tong, and K. De Yao, "Interaction of functional groups of gelatin and montmorillonite in nanocomposite," Journal of Applied Polymer Science, vol. 101, no. 3, pp. 1556-1561, 2006.

[36] G. G. D. Silva, P. J. A. Sobral, R. A. Carvalho, P. V. A. Bergo, O. Mendieta-Taboada, and A. M. Q. B. Habitante, "Biodegradable films based on blends of gelatin and poly (vinyl alcohol): effect of PVA type or concentration on some physical properties of films," Journal of Polymers and the Environment, vol. 16, no. 4, pp. 276-285, 2008.

[37] J.-W. Rhim, "Effect of clay contents on mechanical and water vapor barrier properties of agar-based nanocomposite films," Carbohydrate Polymers, vol. 86, no. 2, pp. 691-699, 2011.

[38] A. Hambleton, M.-J. Fabra, F. Debeaufort, C. Dury-Brun, and A. Voilley, "Interface and aroma barrier properties of iotacarrageenan emulsion-based films used for encapsulation of active food compounds," Journal of Food Engineering, vol. 93, no. 1, pp. 80-88, 2009.

[39] T. Mohan, R. Kargl, A. Doliška et al., "Wettability and surface composition of partly and fully regenerated cellulose thin films from trimethylsilyl cellulose," Journal of Colloid and Interface Science, vol. 358, no. 2, pp. 604-610, 2011.

[40] J.-W. Rhim, S.-I. Hong, H.-M. Park, and P. K. W. Ng, "Preparation and characterization of chitosan-based nanocomposite films with antimicrobial activity," Journal of Agricultural and Food Chemistry, vol. 54, no. 16, pp. 5814-5822, 2006. 

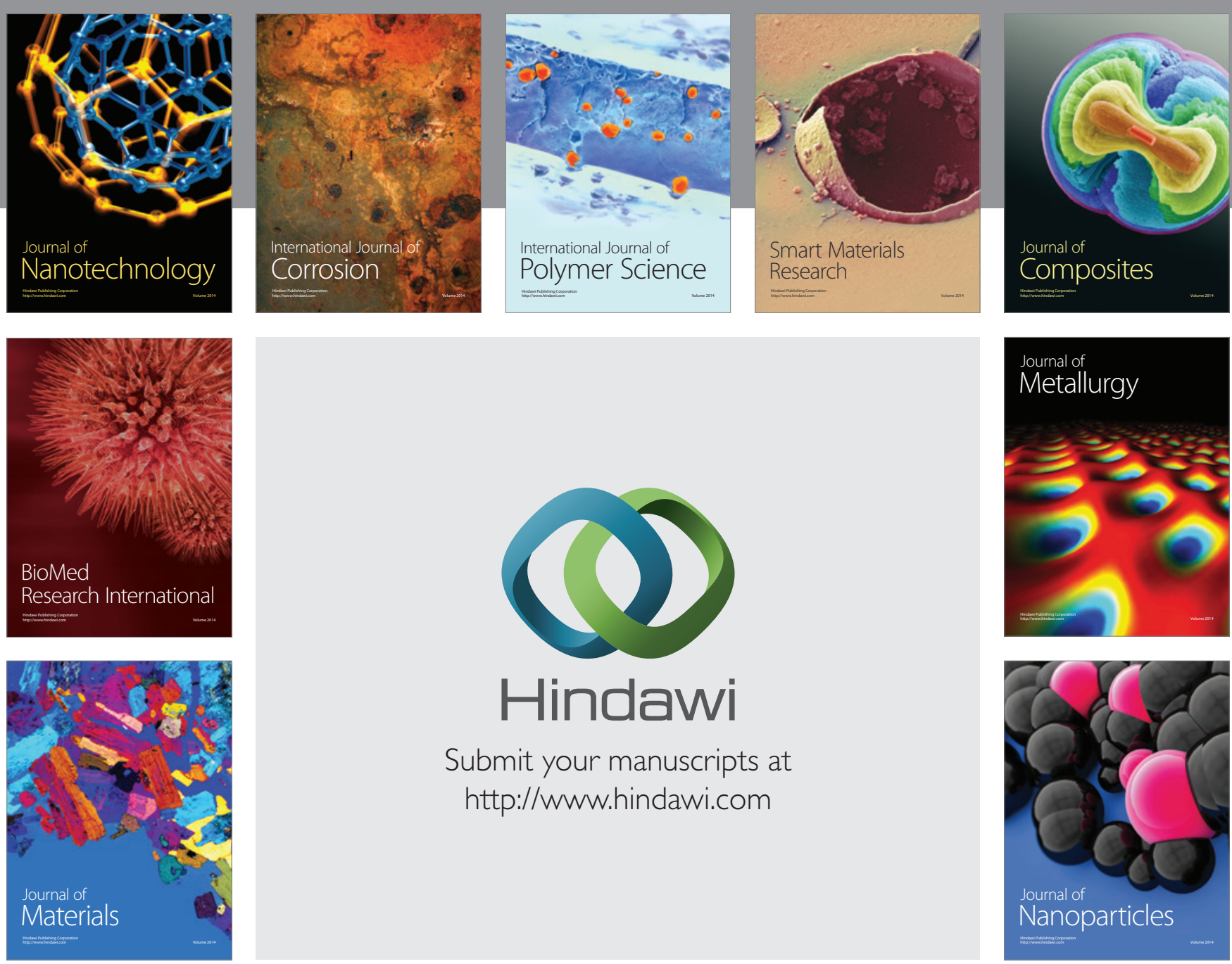

Submit your manuscripts at http://www.hindawi.com
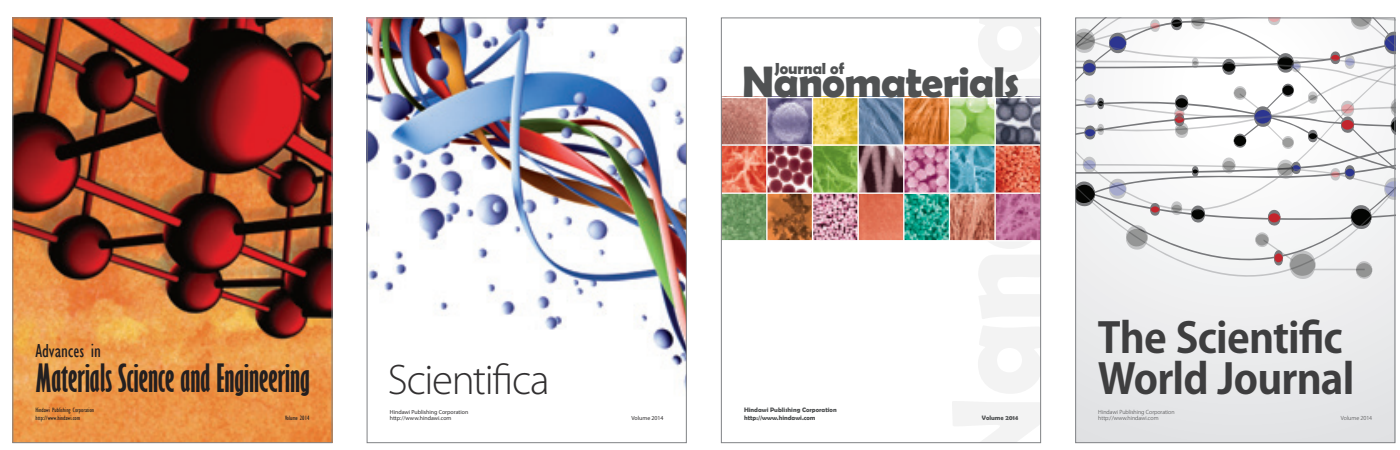

\section{The Scientific World Journal}
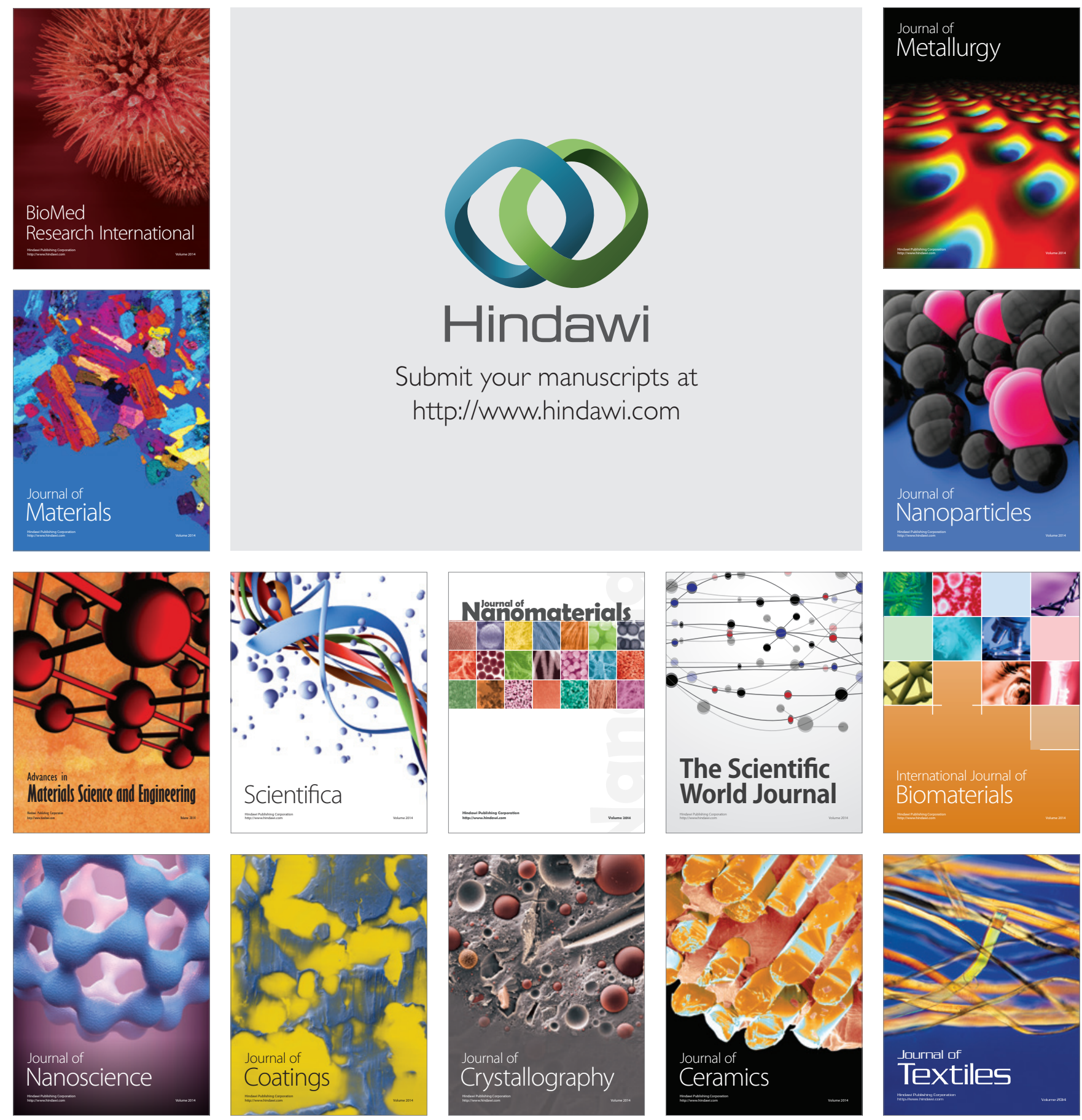